\title{
The Relationship between Ownership Structure and the Probability of a Financial Distress Warning Happening: Evidence of Listed Common Stock Companies in Taiwan
}

\author{
Ching-Chun Wei ${ }^{1}$, Wen-Xin Fang ${ }^{1}$, Guan-Hua $\mathrm{Li}^{1}$, Yu-Wen Kao ${ }^{1}$, Miao-Lin Tsai ${ }^{1}$, Ching-Yi Yang ${ }^{1}$ \\ ${ }^{1}$ Department of Finance, School of Management, Providence University, Taichung, Taiwan \\ Correspondence: Ching-Chun Wei, Department of Finance, School of Management, Providence University, Taichung \\ City, 43301 Taiwan.
}

Received: August 31, 2016

Accepted:September 28, 2016

Available online: October 8, 2016

doi:10.11114/aef.v4i1.1847

URL: http://dx.doi.org/10.11114/aef.v4i1.1847

\begin{abstract}
This paper discusses about the ownership structure of firms and the probability of a financial distress warning happening in Taiwan. Our sample covers all listed common stock companiesexceptthe financial industry from 2006 to 2014. This study usesthe Z-score to measure the probability of firms' financial distress warning happening and employs the shareholding ratio of managerial share ownership, the shareholding ratio of financial institutional investors, and the size of the board of directors to measure firms' ownership structure. For our results, the shareholding ratio of managerial share ownership has positive relationship with the probability of a financial distress warning happening, while the shareholding ratio of institutional investors and the size of the board of directors have a negative relationship with the probability of the same warning happening.
\end{abstract}

Keywords: ownership structure, financial distress warming, shareholding ratio of investors, board ofdirectors

JEL Classification:C58,D53,G11, G31, M14

\section{Introduction}

The Organization of Economic Cooperation and Development(OECD) considers that a board of directors helps investigate and guide company strategy, inspects firm performance, chooses a high level agent of business,, and ensures the correct accounting of the company and its financial reporting. The board of directors are requested to handle company business, make fair and objective judgments, and have enough external board of director member who will exercise their independent judgment when the firm faces a business conflict or negative condition. In addition to holding effective meetings, the board of director's members should have enough time and power to immediately obtain accurate information to implement their job.

In order to control for risk, this study follows the principle of corporate governance, as formulated by OECD in 1998.In order to reduce risk and pursue the highest benefit, a board of directors has toprotecting shareholders rights, give equitable shareholder treatment, and be responsible for company financial.

In 2006a crisis occurred in Taiwan when China Rebar, a listed firm, was found to have conducted severe embezzlement and illegally over-extended a large amount of loans. Following this event, Taiwan's Financial Supervisory Commission(FSC) decided to raise the standard of corporate governance and control risk, focusing on making many changes. The rule of corporate governance was deep in the mechanism, as strong as possiblethe interterm of corporate governance. As a result, FSC's actions helped to raise the efficiency of corporate governance and pushed company boards of directors to take part in the governance.

The agency problem has always existed in companies. One of the agency problems is external creditorsandshareholders, whileanother is internal managers and shareholders. Agency problems have frequently occurred in Taiwan, such as the examples of Pacific Electric Wire \& Cablein 2003, Bardon-Chinese Media Agency in 2004,ChinaRebarin 2007, etc. These company eventsbrought about a financial crisis to the market both big and small, and there was never a strong monitor mechanism installed internally. If an internal monitor mechanism does not work, then such a financial crisis can easily severely influence social stability and financial order. 
Since there are many types of pyramid structure existing in Taiwan, we discuss the corporate ownership structure in this paper. Lemmon \& Lins (2001) support that firms, througha pyramid structure and cross-shareholdings, expand and deviate the degree of cash flow and control rights, leading the controllingowner to hold most of the company's assets. Therefore, as the controlling owner has more ownership, the firm's value suffers more damage.

The agency problem has a negative impact on financial performance. When the goals of managers and shareholders are different, the manager will make unwise decisions that reduce the firm's financial performance and harm shareholders' benefits. If the firms do not have a good internal governance mechanism, then they are open to exposure to many forms of risk. Lower financial performance and such risk exposure will make these firms remain stuck in difficult operating situations. Thus, we discuss the relationship between corporate ownership structure and financial distress warning in this paper.

The rest of the study is formulated as follows. Section 2 describes the related literature on corporate ownership structure and financial distress warning. We then present hypothesis development in section 3. Section 4 illustrates the dataset and the variables.Section 5 analyzes the empirical results. Finally, section 6 provides the conclusion for this paper.

\section{Literature Review}

\subsection{Ownership Structure}

In prior research, there are three relationships between ownership structure and financial performance. From point of corporate ownership structure, many scholars have different views on managers who hold shares that influence corporate value. Here, we discuss these relationships in sequence as: positive, negative, and without relation.

\subsubsection{Positive Relationship}

Jensen \&Meckling (1976) examine the convergence of the interest hypothesis, whereby in order to reduce agency cost, those at the managerial level hold the same high number of shares as the director of external stakeholders. Managers will actively runthe firm and make its efficiency grow better, and thus a financial crisis will not easily take place. Sincefirmmanagement also enjoys its achievement, when the company loses money, the agent also becomes burdened with the loss.

The extensive literature on the convergence of interest hypothesiswas first formalized by Jensen \&Meckling (1976), whonoted that because the shareholdings areconcentrated in the hands ofmanagers, these managers take the responsibility to expand corporate wealth, and so they would not waste money trying to make the firmefficient.If the ownership concentration is with the major shareholders, then they would have some reason to control the firm's managers. For example, major shareholders not only can make good performance, but also can create high corporate value. Therefore, corporate value and performance would have the positive.

Chenet al. (2014) finds thatwhen the interaction between major shareholders increases, the average of the board of directors related to corporate value and stock price will show a better corporate performance, the interaction between outside major stockholders will decrease, and the board of directors will increase related to corporate value and stock price.

\subsubsection{Negative Relationship}

The conflict of interest hypothesis (Jensen \&Ruback, 1983) suggests that managers who have a higher shareholding ratio will neglect the benefit of shareholders. As a result, when managers reject a higher valuation from a takeover bid or be in conflict with the benefits of minority shareholders, this causes the firm to be in a poor financial situation. Fan\& Wong (2002) \& Liu (2012) note anegative relationship between the insider shareholding ratio and financial performance. Both of those studies' evidence fits in withthe conflict of interest hypothesis.

Demsetz (1983) advances the entrenchment hypothesis, which parallels the conflict of interest hypothesis. This hypothesis suggests that there is a negative relationship between the shareholding ratio of managers and financial performance or firm value. When shareholdings are centralized with managers, anti-takeover behavior activities usually occur, such as managersrejecting a merger and acquisition case that is valuable to shareholders. As a result, the expenditure preference ofmanagers' behavioris more serious, and it willreduce the firm's financial performance and harm the firm's value.

\subsubsection{Withoutrelationship}

Fama (1980) suggests that price value could respond to financial performance, since the capital market is efficient and there is an external supervisionmechanism. When managers work hard to maximize earnings, the external management mechanism will supervise them. Financial performance depends on the external supervisionmechanism and the efficient market hypothesis, and therefore there is no relationship with ownership structure. 


\subsection{Financial Distress Warning}

Sudi\& Jimi (2001) states that there are three stages to corporate bankruptcy. The first oneis the low financial return stage. Inappropriate management leads to a decrease in annual investment returns, productive forces, and salesrate. The second one is the financial structure deterioration stage. As investment returns do not meet expectations, a firm's cash flow decreases, and corporate debt may arise in order to solve the demand for corporate capital, thus leading to a firm's higher debt ratio. The third one is that a crisis reveals a failure stage. At this stage, the corporate has low profitability, bad cash liquidity, and high debt ratio. These problems eventually lead to a corporate default, bounced checks, the corporate announcing bankruptcy, and then the eventual shutdown of the firm.

$\mathrm{Wu}(2002)$ indicates that a financial crisis that happens at the corporate level is not good for performance even in the same industry. In order to avoid the influence of a financial crisis, a corporate could conduct window dressing of its financial statements.Hsieh (2011) suggests that when firms face financial problems, they will manipulate earnings to match analysts' forecasts. Because they need to provide financial reports to investors, managers typically try to delay any serious problem, even employing discretionary accruals or real activities to decorate these reports. Therefore, managers of financially distressed firms will deliver inaccurate information on financial reports, leading to investors getting the wrong information and overestimating the firms' earnings.

The literature has mentioned many cases of financial distress in both Taiwan and abroad, including the use of corporate assets to make more money or conducting illegal trade. In above literatures, financial reports were used to examine the probability of a firm's financial distress warning, and such models can $97.99 \%$ correctly forecast such a warning. In other words, these models are able to judge between normal and financially distressedcorporate.

\subsection{Ownership Structure and Financial Distress Warning}

Lee \&Yeh (2004) find that a corporate governance index has a significantly positive explanatory and forecast ability to a corporate financial crisis. Yeh et al. (2001)show that the better a corporate governance mechanism is, the higher the corporate value will be and the lowerthe possibility is fora financial crisis happening. Therefore, a corporate governance index has a positive relationship with the possibility of financial crisis happening.

Mcconnel\&Servaes (1990) consider that the insider shareholder ratio is an important control mechanism and has a positive correlation with corporate value. In the prior literature of domestic, Yeh\&Chiu (1996) state that the relevance of a listed corporate's ownership structure and the company value correspond to the convergence of interest hypothesis in Taiwan. Therefore, ahigher shareholding ratio of directors and supervisors will be more consistent with the benefits to external shareholders, directors and supervisors andimply strong supervision and self-discipline. Chiang (2013) finds that the shareholding ratio of domestic institutions and dealers, who are two kinds of institutional investorsinTaiwan's capital market, significantly decreases before a financial crisis happens.

In order to develop a financial distress warningsystem and risk management, Chiu (2012) considers the agency problem and finds which variable would affect a firm's financial performance in order to estimate the probability of a financial crisis happening. Evidence shows that firms setting up independent directorships could reduce the probability of risk happening and increase the power of corporate governance. Thus, the firms canimprove their performance and stave offa financial crisis.

\section{Hypothesis}

When a corporateis involved in an embezzling or financial crisis, the shareholding ratio of managerial share ownership can be an important signal if insiders are selling their shares quickly. Compared to a normal company, when the shareholdings of directors and supervisors of a company turn lower and there is a higher amount of pledged shares by directors, this could positively prove that a financial crisis is about to happen. Companies under a financial crisis typically have a situation where the chairperson of the board is also the head manager. Therefore, this situation has a positive relationship to the probability of a financial crisis happening.

Leland \& Pyle (1977) state thatthe agency theory believes that higher managerial share ownership implies higher corporate performance.Watson (2013) examines how ownership is related to financing, noting the negative relationship of ownership concentration with financial leverage and the positive relationship of managerial share ownership with financial leverage.

From the static tradeoff theory, when there is higher financial leverage, the probability of a financial crisis erupting will become a constant problem. This means the cost from a financial crisis cost may offset the benefit from financing. Therefore, it will be positive inmanagerial share ownership, financial leverage, and financial crisis. Based on the above literature, we state the hypothesis as below.

H1: There is apositive relationship between the shareholding ratio of managerial share ownership and the probability of a financial distress warning happening. 
Liping (2006) shows that institutional investors who are external shareholders have a negative relationship with their firms' financial performance. Financial institutions do not execute monitoring and promoting functions. Since the financial institutions are institutional investors, they just want to obtain a capital return rather than be involved in strategic investments. Therefore, financial institutions do not actively participate in the corporate strategy of listed companies. At the same time, financial institutions take advantage of funds and information to potentially manipulate the stock prices of listed companies and interfere in corporates' normal operations. Liu (2012) finds that the shareholding ratio of financial institutional investors, when it is not over eight percent, has a positive relationship with corporate performance and corresponds to the convergence of interest hypothesis. If the shareholding ratio of financial institutional investors is over eight percent, there is a negative relationship with corporate performance and corresponds to the conflict of interest hypothesis.

$\mathrm{H} 2$ : There is apositiverelationship between the shareholding ratio of financial institutional investors and the probability of a financial distress warning happening.

Prior research suggests that institutional investors play an important role in supervising managers (Seetharaman et al., 2001; Agrawal\&Mandelker, 1990), and the shareholding ratio of institutional investors is an index of corporate government (Cremers\& Nair, 2005; Monks \&Minow, 1995).Pound (1988) advances the efficient monitoring hypothesis, which considers institutional investors have more advantages, such as professional knowledge, information, and capital. For this reason, institutional investors can supervise with low cost efficiency, thereby decreasing agency problems and increasing performance. Therefore, there is a positive relationship between the shareholding ratio of institutional investors and financial performance.

Balsam et al. (2002)\&McConnel\&Servaes (1990)supportthe efficient monitoring hypothesis, finding that the shareholding ratio of institutional investors could enhance the supervision ofmanagers. Coffee (1991) also supports this hypothesis, since institutional investors would want to hold out for a higher per share price in order to sell at greater profit. For this reason, institutional investors would supervise managers positively. The evidence shows that the shareholding ratio of institutional investors has a negative relationship with financial performance. However, the probability ofa financial distress warninghappening will decrease if the firmexhibits high financial performance. Hence, we infer that the shareholding ratio of institutional investors has anegative relationship with the probability of a financial distress warning happening.

H3: There is a negative relationship between the shareholding ratio of institutional investors and the probability of a financial distress warning happening.

Lipton \&Lorsch (1992)suggestthat the scale of the board of directors and corporate performance has a positive relationship.A large board of directors is able tohelp supervise the corporate in making a good financial performance. Chiu (2012) propose that positive returns due to corporate performance help reduce risk. In order to reduce the probability of risk, setting up independent directors and supervisors not only can assist in financing decisions, but also can raise the performance of corporate governance. Therefore, there is a positive relationship between the scale of board of directors and corporate performance, thus reducing the probability of a financial crisis.

Bacon (1973) considers that a large board of directors could contain many different kinds of field specialists who have professional knowledge, and hence they would put their heads together so as to get better results from firm decisions. Therefore, the size of the board of directors has a positive relationship with financial performance. Rindova (1999) also suggests that firms could broaden the size of the board of directors, because specialists in different fields could handle threats and opportunities from changes in business conditions. A larger size of the board of directors has more powerful supervision and many external resources, thereby influencing firm performance. Since the probability of a financial distress warning happening will increase when the firm's financial performance is not good, we infer that the size of the board of directors has anegativerelationshipwith such probability.

H4: There is a negative relationship between the size of the board of directors and the probability of a financial distress warning happening.

\section{Data and Methodology}

\subsection{Sample Description}

We extracted the datafromthe Taiwan Economic Journal (TEJ) databasefortheyears 2006-2014. Thedata sample includesTaiwanpubliclylisted companies for atotal sample of 7,801 dataobservations. Sincecorporategovernancespecificationswere initiated in 2006, weanalyzethe impacts after this change and whether a company's finances turnedsounder. 


\subsection{Variables}

\subsubsection{Dependent Variable}

We use the dummy variable of the Z-Score to calculate the company's value to predict the possibility of the firm goingbankrupt in two years. TheZ-Score modelisfromEdward Altman in 1968.He uses 22 financial ratios to build five variable Z-score models. TheZ-score model is a formula with many finance variables. It measures a company's financialcondition and estimates the possibility of company bankruptcy within 2 years.

$$
\mathrm{Z}=1.2 x_{1}+1.4 x_{2}+3.3 x_{3}+0.6 x_{4}+0.99 x_{5}
$$

$\mathrm{x}_{1}=$ working capital/total assets. This variable reflects the ability and scale characteristics of a company's property and assets. Ifthe working capital of a companycontinuouslydecreases, then it usually indicatesthe company has cash flow problems or has a crisis of repaying debt in the near term.

$\mathrm{x}_{2}=$ retained earnings/total assets. This reflects the accumulation of company profits. When there is more income, there is agreater surplus ability for the company topay interest on its shares.

$\mathrm{x}_{3}=$ operating profit/total assets. This evaluates the company's profit margin.

$\mathrm{x}_{4}=$ market value/gross liability. This reflects the size of firm value.

$\mathrm{x}_{5}=$ sales income/total assets. This reflects the total operation ability of the enterprise and the management efficiency of total assets.

If the $\mathrm{Z}$ value is smaller, then the probability of a company financial crisis happening ishigher; if the $\mathrm{Z}$ value is larger, then the probability is smaller.Therefore, accordingtothe $Z$-score definition, we set up dependent variableas a dummy. If the $\mathrm{Z}$ valueis more than 2.675 ,then the financial standing of the company is good and bankruptcy possibility is the smallest. However, if the $\mathrm{Z}$ value is less than 2.675 , then bankruptcy possibility is the biggest.

\subsubsection{Independent Variable}

This study consists of four independent variables. The first is the shareholding ratio of managers. For each listed company, we look at the first five largest shareholders and total up their shareholding ratio. If the ratio is more than $10 \%$, then we denote it as 1; otherwise, 0.The second is the financial institutions shareholding ratio. This ratio is domestic financialinstitutions shareholding ratio plus foreign financial institutions shareholding ratio.The third variable is the foundationsshareholding ratio. This ratio is the sum of the ratios of domestic government shareholding, domestic trust funds, domestic company foundations, domestic other foundations, foreign trust funds, and foreign foundations. The last independent variable is the scale of the board of directors. We use the number of directors to measure the size of the board of directors.

\subsubsection{Control Variable}

(1)Debt Ratio $=($ gross liability/total assets $) \times 100 \%$

(2)Company Size $=\ln$ (total assets)

(3)Return on Assets=(before the tax before the interest often continuousnet

$$
\text { profit before depreciating/average total assets) } \times 100 \%
$$

\subsubsection{Construction of Financial Crisis in the Logit Model}

According Altman (1968), we use multiple discriminate analysis to predict whether companies are in a financial crisis. We employ the five representative financial variables to establish the Z-Score model. Moreover, the Z-Score model is used to calculate $\mathrm{z}$-scores; if the value is greater than 2.675 , then it implies normal companies $(\mathrm{Y}=0)$; if the value is less than 2.675, then companies are heading for a financial crisis $(\mathrm{Y}=1)$. Finally, we use alogit model to predict the bankruptcy possibility of a company.

$$
\mathrm{Y}(\mathrm{Z})=\beta_{0}+\beta_{1} \mathrm{MGT}_{\text {HOLDING } 1}+\beta_{2} \mathrm{FIN}_{\text {HOLDING }}+\beta_{3} \mathrm{CRO}_{\text {HOLDING }}+\beta_{4} \mathrm{BS}+\beta_{5} \text { CONTROL }
$$

In equation (2), MGT_HOLDING_D1 is a dummy variable. If the manager shareholding ratio value is more than $10 \%$, then it is denoted by 1 ; if the value is less than $10 \%$, then 0 . Other variables are defined as noted above.

\section{Empirical Results}

\subsection{Descriptive Statistics}

Table 1 is the descriptive statistics ofeach variable's value. According to the following table, we are able to understand the changein the number of data distribution situationthroughdescriptive statistics analysis. 
Table 1. Descriptive Summary Statistics

\begin{tabular}{|c|c|c|c|c|c|c|c|c|}
\hline & $\mathrm{Z}$ & MGT_HOI & FIN_HOLI & SCRO_HOI & $\mathrm{sBS}$ & DEBT & SCALE & ROA \\
\hline Mean & 0.588115 & 0.980435 & 2.655023 & 38.33231 & 4.941451 & 44.29571 & 27165.03 & 9.245166 \\
\hline Median & 1.000000 & 1.000000 & 0.530000 & 35.85000 & 4.000000 & 43.76000 & 5420.000 & 8.000000 \\
\hline Maximum & 1.000000 & 1.000000 & 56.51000 & 99.99000 & 14.00000 & 99.13000 & 3656082 . & 96.00000 \\
\hline Minimum & 0.000000 & 0.000000 & 0.000000 & 0.000000 & 0.000000 & 1.270000 & 40.00000 & -89.80000 \\
\hline Std. Dev. & 0.492210 & 0.138510 & 4.797335 & 22.15434 & 2.123987 & 19.85648 & 111885.3 & 8.872008 \\
\hline Skewness & -0.358064 & -6.937715 & 3.631249 & 0.381232 & 1.198834 & 0.379763 & 14.33938 & 0.152088 \\
\hline Kurtosis & 1.128210 & 49.13190 & 22.54571 & 2.289702 & 5.425574 & 2.896642 & 314.1092 & 9.827689 \\
\hline Jarque-Bera & 1146.191 & 662263.9 & 124075.0 & 309.8819 & 3319.546 & 167.6755 & 27855852 & 13329.83 \\
\hline Probability & 0.000000 & 0.000000 & 0.000000 & 0.000000 & 0.000000 & 0.000000 & 0.000000 & 0.000000 \\
\hline Sum & 4028.000 & 6715.000 & 18184.25 & 262538.0 & 33844.00 & 303381.4 & $1.86 \mathrm{E}+08$ & 63320.14 \\
\hline Sum Sq. Dev. & 1659.073 & 131.3783 & 157602.7 & 3361100. & 30893.52 & 2700027. & $8.57 \mathrm{E}+13$ & 539023.4 \\
\hline Observations & 6849 & 6849 & 6849 & 6849 & 6849 & 6849 & 6849 & 6849 \\
\hline
\end{tabular}

5.2 Correlation Coefficient Analysis

By the correlation coefficient analysis in Table 2, each variable value of the correlation coefficient is smaller than0.8, and all relativities are not high. Thus, the correlation between each variable is not high, implying there is nocollinearity.

Table 2. Correlation Coefficients of Variables

\begin{tabular}{|c|c|c|c|c|c|c|c|c|}
\hline \multirow{2}{*}{$\frac{\text { Probability }}{Z}$} & \multirow{2}{*}{$\frac{\mathrm{Z}}{1.000000}$} & \multicolumn{4}{|c|}{ MGT_HOLDINGFIN_HOLDINGCRO_HOLDINGBS } & \multirow[t]{2}{*}{ DEBT } & \multirow[t]{2}{*}{ SCALE } & \multirow[t]{2}{*}{$\mathrm{ROA}$} \\
\hline & & & & & & & & \\
\hline & ----- & & & & & & & \\
\hline \multicolumn{2}{|c|}{ MGT_HOLDING-0.000412 } & 1.000000 & & & & & & \\
\hline & 0.9728 & ----- & & & & & & \\
\hline \multirow[t]{2}{*}{ FIN_HOLDING } & 0.029449 & 0.019859 & 1.000000 & & & & & \\
\hline & 0.0148 & 0.1003 & ----- & & & & & \\
\hline \multirow[t]{2}{*}{ CRO_HOLDING } & -0.001263 & -0.008967 & 0.070830 & 1.000000 & & & & \\
\hline & 0.9168 & 0.4581 & 0.0000 & ----- & & & & \\
\hline \multirow[t]{2}{*}{ BS } & 0.123454 & 7.67E-05 & 0.121191 & 0.182321 & 1.000000 & & & \\
\hline & 0.0000 & 0.9949 & 0.0000 & 0.0000 & ----- & & & \\
\hline \multirow[t]{2}{*}{ DEBT } & 0.594015 & 0.029103 & 0.156169 & 0.088677 & 0.117196 & 1.000000 & & \\
\hline & 0.0000 & 0.0160 & 0.0000 & 0.0000 & 0.0000 & ----- & & \\
\hline \multirow[t]{2}{*}{ SCALE } & -0.037133 & -0.000419 & 0.168394 & 0.249696 & 0.080032 & 0.049208 & 1.000000 & \\
\hline & 0.0021 & 0.9723 & 0.0000 & 0.0000 & 0.0000 & 0.0000 & ----- & \\
\hline \multirow[t]{2}{*}{ ROA } & -0.379622 & -0.014200 & 0.086935 & 0.189626 & -0.108828 & -0.314650 & 0.158007 & 1.000000 \\
\hline & 0.0000 & 0.2400 & 0.0000 & 0.0000 & 0.0000 & 0.0000 & 0.0000 & ----- \\
\hline
\end{tabular}

\subsection{Empirical Results of Logistic Regression}

Based on Prob. (LR statistic), the whole model is significant. Table 3 shows that the structure of ownership and the size of Directors, Managers Shareholding Ratio, Foundations Shareholding Ratio, and the Board of Directors Scale are all significant. For the parameters' estimated value, when the Managers Shareholding Ratio is higher, that representative company's possibility of a financial crisis happening will be reduced; this representative firm with an equity structure too concentrated in management's or internal people's hands means that management will be charged with incurring any wealth loss, thus making managers' behavior more reasonable and hence reducing a, thus reduced company's agency problem,

For the logit model, the result that a higher financial institutions shareholding ratio implies a higher possibility of a financial crisis is not statistically significant. This could be due to financial institutions invest for investment purposes only and do not have the interests of policy holders in mind. Thus, they will not play any monitoring role and that there is no significant relationship between the sharesheld by financial institutions and firms 'financial performance.Forthe foundations shareholding ratio, when foundations shareholding ratio is higher,the possibility of a financial crisis is 
bigger. Another reason is according to Wang et al. (2008), who notes the significantly negative relationship between the government institutions holding ratio and company business performance, probably because a higher government stake in a company means the board's decisions shall be subject to the approval of the government. Such decisions are made with a lack of flexibility and have an adverse impact on business performance, thus raising the possibility of a financial crisis and hence the positive correlation in the model.

According to Yermack (1996), Thus, a larger size of the board of directors increasesthe possibility of a financial crisis happening. The statistics are significant and positively related. Conyon\& Peck (1998), Eisenberg et al. (1998), \&Hermalin and Weisbach (2001) also confirm that a smallerscale of the board will result in betterfinancialperformancefor firms.

Table 3. The Empirical Results of Logit Regression

\begin{tabular}{lccc}
\hline Z_score(Y variable) & Model \\
\hline Constant & $-3.1343^{* * *}$ \\
MGT_HOLDING & $-0.4677^{* * *}$ \\
FIN_HOLDING & 0.0117 \\
CRO_HOLDING & & $0.0033^{* * *}$ & \\
BS & & $0.1206^{* * *}$ & \\
DEBT & & $0.1037^{* * *}$ & \\
SCALE & & $-1.92 \mathrm{E}-06^{* * *}$ & \\
ROA & & $-0.1022^{* * *}$ & \\
\hline McFadden R-squared & & Mean dependent var. & 0.588115 \\
S.D. dependent var. & 0.403792 & S.E. of regression & 0.355355 \\
Akaike info. criterion & 0.492210 & Sum squared resid. & 863.8627 \\
Schwarz criterion & 0.810242 & Log likelihood & -2766.675 \\
Hannan-Quinn criter. & 0.818222 & Deviance & 5533.350 \\
Restr. Deviance & 0.812995 & Restr. log likelihood & -4640.453 \\
LR statistic & 9280.905 & Avg. log likelihood & -0.403953 \\
Prob.(LR statistic) & 3747.556 & & \\
\hline Obs. with Dep.=0 & 0.000000 & Total obs. & 6849 \\
Obs. with Dep.=1 & 2821 & & \\
\hline
\end{tabular}

Notes: $* * * * *$ and $*$ indicated at least significant at $1 \%, 5 \%$ and $10 \%$ level,respectively.

\section{Conclusion}

With the growth of today's business organizations, company managers are sometimes sacrificing the interests of shareholders at their own expense, while at the same time company directors and supervisors are not playing the role of an oversight mechanism. Taiwan's laws offer weak protection of minority shareholders' rights, resulting in it being difficult to protect the interests of investors and creditors, and so the level of a company's corporate governance is quite important. Corporate governance is part of a firm's ownership structure. Conflicts of interest can easily form between controlling shareholders and minority shareholders, with the worst case leading to a financial crisis in the company. In recent years, many global enterprises have encountered financial fraud and/or financial crises, resulting in shocks to various financial markets. So, discussion the effect of equity structure and the Board structure on company occurred possibility of financial crisis, and less literature for equity structure to discussion the problem of financial default, so this study aims to explore the high or low of managers shareholding ratio, financial institutions shareholding ratio, foundations shareholding ratio and the board of directors scale which impact of financial crisis in of the company.This study has used a logit model for verification and empirical analysis. Our results show that legal ownership and board size are positively related to the probability of a financial crisis in a company. When the foundations shareholding ratio and the size of the board of directors are higher, there is a greater probability of a financial crisis in the company. The empirical results show that the debt ratio, ROA, and size are all statistically significant, representing that when the debt 
ratio is high, it is more likely for the company to encounter bankruptcy; when ROA and size are lower, the company also faces the possibility of a financial crisis.

\section{Acknowledgements}

The author would like to thanks two anonymousreferees for helpful comments and suggestions that have improved the quality of the paper.

\section{References}

Agrawal, A., \& Mandelker, G. (1990).Large shareholders and the monitoring of managers, the case of antitakeover charter amendment.Journal of Financial and Quantitative analysis,25, 143-167.http://dx.doi.org/10.2307/2330821

Altman, E. I. (1968). Financial ratios, discriminate analysis and the prediction of corporate bankruptcy. The Journal of Finance, 1, 589-609.http://dx.doi.org/10.1111/j.1540-6261.1968.tb00843.x

Bacon, R. (1973). The Theory of Board.Research Management, 29, 133-165.

Balsam, S. B. E., \& Marquardt, C. (2002). Accruals Management, Investor Sophistication, and Equity Valuation: Evidence from 10-Q Filings. Journalof Accounting Research, 40 , 987-1012.http://dx.doi.org/10.1111/1475-679X.00079

Chen, Y. W. Y., \& Le, L. (2014).Independent directors' board networks and controlling shareholders tunneling behavior.China Journal of Accounting Research, 7, 101-118.http://dx.doi.org/10.1016/j.cjar.2013.09.002

Chiang, H. T., \& Ching, Y. C. (2013).Government ownership and corporate performance: evidence from green technology industry in Taiwan. Investment Management and Financial Innovations, 10, 46-56.

Chiu, I. H. Y. Y. (2012). Macroprudential supervision: critically examing the developments in the UK, EU and internationally. Law \& Financial Market Review, 6, 184-199.http://dx.doi.org/10.5235/175214412800650563

Coffee, J. C. (1991). Liquidity versus Control: The Institutional Investor as Corporate Monitor. Columbia Law Review, 91, 1277-1368.http://dx.doi.org/10.2307/1123064

Conyon, M. J., \& Peck, S. I. (1998). Board Size and Corporate Performance: Evidence from EuropeanCountries.The European Journal of Finance, 4, 291-304.http://dx.doi.org/10.1080/135184798337317

Cremers, K., \& Nair, V. (2005).Governance mechanisms and equity prices.Journal of Finance, 60, 2859-2894.http://dx.doi.org/10.1111/j.1540-6261.2005.00819.x

Demsetz, H. (1983). The Structure of Ownership and the Theory of the Firm.Journal of Law and Economics, 26, 375-390. http://dx.doi.org/10.1086/467041

Eisenberg, T. S. S., \& Wells, M. T.(1998).Larger Board Size and DecreasingFirm Value in Small Firms.Journal of Financial Economics, 48, 35-54.http://dx.doi.org/10.1016/S0304-405X(98)00003-8

Fama, E. (1980). Agency Problems and the Theory of the Firm.Journal of Political Economy, 88(2), 288-307.http://dx.doi.org/10.1086/260866

Fan, P. H.,\& Wong, T. J. (2002).Corporate Ownership Structure and the Information of Accounting Earnings in East Asia.Journal of Accounting and Economics, 33, 401-425.http://dx.doi.org/10.1016/S0165-4101(02)00047-2

Hermalin, B. E., \& Weisbach, M.(2001). Boards of Directors as an EndogenouslyDeterminedInstitution: A Survey of the Economic Literature. Economic PolicyReview, 7-26.

Hsieh, M. F., \& J-C, C. (2011).Can the street information improve the corporate distress diagnosis? evidence from Taiwan. International Review of Accounting Banking \& Finance, 3, 70-92.

Jensen, M. C., \& Meckling, W. H. (1976). Theory of the Firm: Managerial Behavior, Agency Costand Ownership Structure. Journal of Financial Economics, 3, 305-360.http://dx.doi.org/10.1016/0304-405X(76)90026-X

Jensen, M. C., \& Ruback, R. S. (1983).Market for corporate control: empirical evidence.Journalof Financial Economics, 1, 5-50.http://dx.doi.org/10.1016/0304-405X(83)90004-1

Lee, T. S., \&Yeh, H. Y. (2004). Corporate governance and financial distress: evidence from Taiwan. Journal of Corporate Governance, 12(3), 378-388.http://dx.doi.org/10.1111/j.1467-8683.2004.00379.x

Leland, H., \& Pyle, D. (1977).Informational asymmetries, financial structure, and financial intermediation.Journal of Finance, 32(2), 371-384.http://dx.doi.org/10.2307/2326770

Lemmon, M., \& Lins, K. (2001).Ownership structure, corporate governance, and firm value: evidence from the east asian financial crisis. University of Utah working paper: University of Utah press.

Liping, X. (2006).The impact of centralized system, equity checks and balances on corporatePerformance.Economic 
Research Journal, 1, 23-55.

Lipton, M., \& Lorsch, J. (1992). A modest proposal improved corporate governance.Business Lawyer, 48, 59-77.

Liu, J. H. (2012). Board monitoring, management contracting and earning management: an evidence from ASX list companies. International Journal of Economics and Finance, 4, 121-136.http://dx.doi.org/10.5539/ijef.v4n12p121

McConnell, J. J., \& Servaes, H. (1990).Additional evidence on equity ownership andcorporate value.Journal of Financial Economics, 27, 595-612.http://dx.doi.org/10.1016/0304-405X(90)90069-C

Monks, R., \& Minow, N. (1995).Corporate governance. Cambridge, MA: Blackwell.

Morck, R., Shleifer, A., \& Vishny, R. W. (1988). Management ownership and market valuation: An empirical analysis. Journal of Financial Economics, 20, 293-315.http://dx.doi.org/10.1016/0304-405X(88)90048-7

Pound, J. (1988). Proxy contests and the efficiency of shareholder oversight.Journal of Financial Economics, 20, 237-265. http://dx.doi.org/10.1016/0304-405X(88)90046-3

Rindova, V. P. (1999). What corporate boards have to do with strategy: A cognitive perspective.Journal of Management Studies, 26, 953-975. http://dx.doi.org/10.1111/1467-6486.00165

Seetharaman, A., S-L, Z., \& Srindhi, B. (2001). Analytical andempiricalevidence of the impact of tax rates on the trade-off between debt and managerial ownership. Journal of Accounting, Auditing \& Finance, 16, 249-272.

Sudi, S., \& Jim, L. (2001). Corporate financial distress and turn around strategies: an empirical analysis. British Journal of Management, 12, 183-199. http://dx.doi.org/10.1111/1467-8551.00193

Wang, J. S., Chen, J. T., \& Chou, P. H. (2008). Market reactions to the passage of the financial holding company act in Taiwan. Pacific Economic Review, 13, 453-472.http://dx.doi.org/10.1111/j.1468-0106.2008.00412.x

Watson, R. (2013). Financial leverage and corporate governance.The Oxford Handbook of Corporate Governance, 1 , 269-289.http://dx.doi.org/10.1093/oxfordhb/9780199642007.013.0012

Wu, S. K. (2002). Ownership structure and firm performance: an empirical research on China public companies. China Industrial Economy, 3, 32-43.

Yeh, Y. H., \& Chiu, S.B. (1996). Ownership structure, capital structure, and firm value: A study of agency theory on Taiwan Stock Market. NTU Management Review, 7, 57-90.

Yeh, Y. H., Lee, T. S., \& Lee,T. W. (2001). Family control and corporate governance: evidence from Taiwan. International Review of Finance, 2, 21-48.http://dx.doi.org/10.1111/1468-2443.00014

Yermack, D.(1996). Higher market valuation of companies with a small board ofdirectors.Journal of Financial Economics, 40(2), 185-211.http://dx.doi.org/10.1016/0304-405X(95)00844-5

\section{Copyrights}

Copyright for this article is retained by the author(s), with first publication rights granted to the journal.

This is an open-access article distributed under the terms and conditions of the Creative Commons Attribution license which permits unrestricted use, distribution, and reproduction in any medium, provided the original work is properly cited. 